\title{
The Salience of a Career Calling Among College Students: Exploring Group Differences and Links to Religiousness, Life Meaning, and Life Satisfaction
}

\author{
Ryan D. Duffy \\ William E. Sedlacek
}

\begin{abstract}
The authors examined the degree to which lst-year college students endorse a career calling and how levels of calling differ across demographic variables and religiousness, life meaning, and life satisfaction. Forty-four percent of students believed that having a career calling was mostly or totally true of them, and $28 \%$ responded to searching for a calling in the same fashion. Students seeking advanced professional degrees were more likely to feel a career calling, and the presence of a calling was found to weakly correlate with religiousness and life satisfaction and moderately correlate with life meaning. Practice implications are suggested.
\end{abstract}

In its century-old form, the term calling meant a direct call by God to a religious vocation. Today, this term has grown to take on a variety of meanings and is often applied to both religious and nonreligious career paths (Dik \& Duffy, 2009). Within the career literature, relatively little empirical research has been completed to understand the degree to which specific populations endorse this construct and in turn how having the presence of, or searching for, a career calling relates to demographic and psychological variables. The purpose of the present study was to explore the salience of this construct for student populations; determine which groups of students are most likely to endorse a career calling; and determine how having a career calling, or searching for one, relates to religiousness, life meaning, and life satisfaction.

The term calling is not represented in any of the major theories of career choice. Nevertheless, we believe that Super's (1990) developmental model of career development may provide the most useful framework for conceptualizing the potential role of a career calling in students' career decision making. First, perhaps more than any other major career development theory, Super's theory emphasizes that an extremely wide range of person and contextual variables may affect career choice. Second, Super's developmental approach provides a theoretical background for the career-related tasks encountered by students in the current study. Super suggested that from the ages of 18

Ryan D. Duffy and William E. Sedlacek, Counseling Center, The University of Maryland. Ryan D. Duffy is now at Department of Psychology, The University of Florida. Correspondence concerning this article should be addressed to Ryan D. Duffy, Department of Psychology, The University of Florida, Gainesville, FL 32606 (e-mail: rduf@ufl.edu).

(C) 2010 by the National Career Development Association. All rights reserved.

The Career Development Quarterly 
to 21 years most individuals are in the specification stage, or engaged in a process of firming their vocational goals. In this stage, students are hypothesized to be actively exploring aspects of themselves, which can be used as information in making major and career choices. Super believed that the formation of goals is influenced by a host of these variables, including both personal variables (e.g., personality, interests, skills, values) and societal variables (e.g., economy, labor market; Super, 1990). Although having a career calling, or searching for one, was not a theme explored by Super, we hypothesize that this construct may represent another important personal variable that could have a significant impact on career decision making.

Career development researchers have paid particular attention to the person variables within Super's (1990) model in an effort to understand the factors that affect college students' career decision making. The most common variables studied are vocational interests, skills, personality, perceived abilities, and work values (Luzzo, 2000; Niles, Erford, Hunt, \& Watts, 1997). Students are theorized to use some combination of these variables in making their ultimate career decisions, and research has shown that the development of these dimensions (e.g., interests, skills, values) is dependent on a host of additional predictor variables. These can include environmental experiences; family influence (Whiston \& Keller, 2004); disability (Hitchings, Luzzo, Retish, Horvath, \& Ristow, 1998); lesbian, gay, bisexual, and transgender identity (Tomlinson \& Fassinger, 2003); educational goals (Meinster \& Rose, 2001); gender (Lippa, 1998); and race or culture (Worthington, Flores, \& Navarro, 2005). In this exploratory study, one of our goals was to understand how some of these previously studied constructs might relate to students' experiences of a career calling. Thus, we explored the extent to which the presence of, or search for, a career calling was related to gender, race, and educational aspirations.

One additional set of variables that may be linked to the development of a calling is an individual's spirituality or religion (Brewer, 2001). Recently, researchers and theorists have begun to explore the mechanisms by which students' spirituality or religion generally relates to their career development (Duffy, 2006; Duffy \& Dik, 2009). For example, students who are religious or spiritual tend to be more mature in their career decision-making process (Duffy \& Blustein, 2005), may use these frameworks as coping mechanisms when facing academic and career difficulties (Constantine, Miville, Warren, Gainor, \& Lewis-Coles, 2006), may be more likely to endorse work values related to meaning and service (Duffy, 2010), and tend to place a higher value on helping others and social justice (Leak, 1992). Religious students may also draw on their relationships with a Higher Power or their religious community for support during their career decision-making process (Duffy \& Lent, 2008).

In their review of the literature on calling, Dik and Duffy (2009) found that a number of definitions of calling have tied it directly to religion or spirituality. Nevertheless, a calling is not always associated with religion or spirituality and has alternatively been described as work that defines one's life purpose (Hall \& Chandler, 2005) and as a career used to serve the greater good (Wrzesniewski, McCauley, Rozin, \& Schwartz, 1997). Most recently, Dik and Duffy attempted to develop an empirically testable definition of a calling. They defined calling as 
a transcendent summons, experienced as originating beyond the self, to approach a particular life role in a manner oriented toward demonstrating or deriving a sense of purpose or meaningfulness and that holds other-oriented values and goals as primary sources of motivation. (Dik \& Duffy, 2009, p. 427)

According to the authors, a calling to a particular career is believed to come from a force outside the person and applies to areas of work that help others in some way and that also provide personal life meaning. This definition has received support from a recent qualitative study with college students (Hunter, Dik, \& Banning, 2010). Given the different perspectives on whether a career calling is religiously based, we explored the extent to which the presence of, or search for, a career calling is related to students' levels of intrinsic religiousness. Here, intrinsic religiousness refers to an internal motivation to live according to one's religious beliefs (Gorsuch \& McPherson, 1989).

The existent empirical research on calling, in both religious and nonreligious contexts, has most often focused on working adults. These studies have generally shown that feeling called to a career has been related to social justice beliefs, increased job security, job satisfaction, life satisfaction, and a greater likelihood of making personal sacrifices for one's job (Bunderson \& Thompson, 2009; Davidson \& Caddell, 1994; Peterson, Park, Hall, \& Seligman, 2009; Serow, 1994; Serow, Eaker, \& Ciechalski, 1992; Wrzesniewski et al., 1997). Nevertheless, research on these constructs as applied specifically to college students has been increasing as well. For example, three qualitative studies that assessed the role of religion or spirituality in the career development of college students found that some students do report a career calling, often coinciding with a desire to serve others in some way (Constantine et al., 2006; Lips-Wiersma, 2002; Royce-Davis \& Stewart, 2000). Additionally, Duffy and Sedlacek (2007) found that college students who had felt the presence of a calling were more likely to be decided and comfortable in their career choices, to view their careers as important, and to have strong vocational self-clarity. Dik, Sargent, and Steger (2008) also surveyed a sample of college students and found the sense of a calling to relate to positive work outcomes expectations and career decision self-efficacy.

Given this prior research, we sought to extend the calling-well-being links with adult populations and determine the extent to which the calling variables relate to life meaning and life satisfaction with a college student sample. In particular, life meaning, or the degree to which individuals believe that their lives have a clear purpose (Steger, Frazier, Oishi, \& Kaler, 2006), and career calling may overlap to the degree that they might be considered the same underlying construct, whereby calling might be viewed as finding meaning in one's career. Conversely, a similar argument could be made that the search for life meaning and the search for a career calling may also be touching the same underlying construct. Thus, in the present study, we sought to explore whether these variables were related as well as distinct from one another.

In summary, although the calling construct was not originally included in Super's (1990) theory, we hypothesized that it might represent a personal variable that may be relevant in the career decision making of 
college students. Super theorized that given their developmental level, this group may be particularly attuned to matching aspects of their personality, values, and interests with major or job choices. It may be that for some students, a career calling represents one additional variable that influences the development of specific career choices. This influence may occur directly (i.e., a student is literally called to a career in the ministry and thus chooses to follow this career path) or indirectly by way of a student's religious or spiritual background.

Although the exact mechanisms by which a career calling relates to a student's career decision process is a critical empirical question, we believed that it was most important to first assess the general degree to which students endorse feeling or searching for this construct. Second, we explored the salience of a career calling for particular groups of students by examining differences in the presence of, and search for, a calling across gender, race, and educational aspirations. Third, the relation between the presence of, and search for, a career calling to religiousness, life meaning, the search for life meaning, and life satisfaction was explored. These variables were chosen because previous researchers have explored these connections among adult populations (e.g., Davidson \& Caddell, 1994; Wrzesniewski et al., 1997), but no research to date had been found looking at the relations among these constructs in 1st-year college students. Ideally, these results can be used to inform future studies in this area of research and provide practice implications for college counselors.

\section{Method}

\section{Participants}

Participants were 5,523 incoming 1 st-year students at a large, midAtlantic, public university who were entering the university in either 2006 or 2007 . Of the total sample, 3,091 of the participants entered the university in 2006 and 2,432 entered in 2007. This sample was $51 \%$ male and $49 \%$ female. Regarding race, $63 \%$ of the participants were European American, 13\% African American, 15\% Asian American, 6\% Latino American, 3\% unknown, and less than 1\% Native American. (Percentages do not equal $100 \%$ because of rounding.) The age range for participants was 17 to 26 years, with a mean age of 17.88 years $(S D=0.50)$ and a median age of 18 years. Also, participants reported the following religious or nonreligious affiliations: $27 \%$ of the participants were Protestant, 25\% Roman Catholic, 15\% Jewish, $10 \%$ agnostic, $10 \%$ atheist, $5 \%$ no preference, $2 \%$ Muslim, $1 \%$ Hindu, and $1 \%$ Buddhist; $4 \%$ did not respond.

\section{Measures}

Presence of a calling. The presence of a career calling was measured by a two-item scale exploring the extent to which college students felt called to pursue a certain career (Dik \& Steger, 2006). Students were asked to consider how true each of these statements was for them and to rate each item on a 5-point Likert-type scale with the following response options: 1 = not at all true of me, 2 = mildly true of me, $3=$ moderately 
true of me, $4=$ mostly true of $m e$, and $5=$ totally true of me. The two items were "I have a calling to a particular kind of work" and "I have a good understanding of my calling as it applies to my career," and the sum of responses on these items was used for the analyses. In the original study, Dik and Steger (2006) constructed this two-item scale to examine the effectiveness of a calling-based career intervention among college students. The authors found the presence of a calling to correlate with career decision self-efficacy, intrinsic work motivation, religious commitment, and life meaning. Additionally, studying another group of college students, Dik et al. (2008) found this scale to positively correlate with religious commitment and spiritual strivings. Dik and Steger estimated the internal consistency reliability of scores from this measure at .86. For the current study, the two items were significantly correlated $(r=.82)$.

Search for a calling. The search for a career calling was measured by a two-item scale exploring the extent to which college students are currently searching for a calling to a certain type of career (Dik \& Steger, 2006 ). As with the previous scale, students were asked to consider how true each of these statements were for them and to rate each item on a 5-point Likert-type scale with the following response options: $1=$ not at all true of me, 2 = mildly true of me, $3=$ moderately true of me, $4=$ mostly true of me, and $5=$ totally true of me. The two items used on this instrument were "I am trying to figure out my calling in my career" and "I am searching for a calling as it applies to my career," and, again, the sum of responses on these items was used for the analyses. Dik and Steger (2006) found the search for a calling to significantly negatively correlate with career decision self-efficacy and to positively correlate with the search for life meaning and religious commitment. These authors also found a strong internal consistency reliability of .87 for participants' scores on this measure. For the current study, the two items were significantly correlated $(r=.78)$.

Educational aspirations. This construct was measured by a single item asking students to indicate the highest academic degree they intended to obtain. Students were given nine options. Examples are "Bachelor's (BA [bachelor of arts] or BS [bachelor of science])," "Master's (MA [master of arts], MS [master of science], MEd [master of education], etc.)," and "Medical (MD [doctor of medicine], OD [doctor of optometry], DDS [doctor of dental surgery], DVM [doctor of veterinary medicine])." For analysis purposes, several of the categories were excluded because of extremely low numbers of student endorsement, which included "Do not expect to complete a degree" and "Associate's (AA [associate in arts] or equivalent)."

Religiousness. The eight-item Intrinsic Religiousness Scale revised by Gorsuch and McPherson's (1989) was used to measure the extent to which participants view their religion as an integral part of their lives and identity. Example items are "My whole approach to life is based on my religion" and "Although I am religious, I don't let it affect my daily life" (reverse coded). Participants responded to these eight items on a 5 -point Likert-type scale ranging from 1 (strongly disagree) to 5 (strongly agree). In the instrument development study, Gorsuch and McPherson found this scale to have adequate internal consistency reliability at the .83 level. This scale has been found to highly correlate with other in- 
dicators of religiousness and significantly correlate with a host of wellbeing outcomes (e.g., Park, Cohen, \& Murch, 1996; Salsman, Brown, Brechting, \& Carlson, 2005). For the current study, we calculated the estimated internal consistency, finding a Cronbach's alpha value of .77.

Life meaning. The degree to which participants believed that their lives were meaningful, or were currently searching for meaning, was measured by a shortened version of the Meaning in Life Questionnaire (MLQ; Steger et al., 2006). Because of space constraints on the survey, we decided to use only four items from the Steger et al. (2006) original 10 -item scale. The two items "My life has a clear sense of purpose" and "I have a good sense of what makes my life meaningful" were used to measure life meaning, and the two items "I am seeking a purpose or mission in life" and "I am searching for meaning in my life" were used to measure the search for life meaning. These items were chosen because they were the highest loading items from Steger et al.'s original instrument. Participants were asked to respond to these items on a 7-point Likert-type scale ranging from 1 (absolutely untrue) to 7 (absolutely true). Although these findings cannot be compared with those for the scales used in the current study, Steger et al. found the full MLQ to have strong validity. The Life Meaning subscale of the full MLQ positively correlated with religiosity, extraversion, agreeableness, and life satisfaction and negatively correlated with depression. The authors also found scores from the Search for Life Meaning subscale from the full MLQ to positively correlate with depression, sadness, and fear. Finally, Steger et al. found each subscale to have adequate internal consistency reliabilities, ranging from .81 to .86 . For the current study, the two life meaning items were found to correlate at .65 and the two search for life meaning items were found to correlate at .70.

Life satisfaction. The degree to which participants find their life satisfying was measured by the five-item Satisfaction With Life Scale (SWLS; Diener, Emmons, Larsen, \& Griffin, 1985). Participants answered each item on a 7-point Likert-type scale ranging from 1 (strongly disagree) to 7 (strongly agree). Sample items are "In most ways my life is close to my ideal" and "I am satisfied with my life." Pavot and Diener (1993) reviewed studies that had used the SWLS and found it to correlate strongly with other indicators of satisfaction and to have adequate internal consistency reliability. For the current study, we calculated the estimated internal consistency, finding a Cronbach's alpha value of .85.

\section{Procedure}

The data were collected over a 2 -year period via the University New Student Census, a questionnaire addressing a variety of attitudinal, behavioral, and demographic variables given yearly to incoming students. For both years, permission was requested and granted by the university's institutional review board to survey students who were 17 , as well as 18 , years or older, without parental consent. This was due to a substantial percentage of incoming students being 17 years old, and this information was included on the informed consent form for both years of data collection. During the lst year, proctors trained by the authors administered the survey; administration occurred within a 35 -minute time period during the incoming students' summer orientation program, with the students' 
informed consent. Only students attending orientation participated in the survey, and all surveys were completed in campus computer labs.

During the 2 nd year, data were collected through an online survey, which allowed students to complete the survey online at their own convenience. Data collection was completed in collaboration with the university's Admissions Office and Institutional Research Office, which had the necessary contact information to reach incoming students. Over the summer, all students enrolled in freshman orientation were sent an e-mail by the Admissions Office requesting their participation with an attached link to the online survey and informed consent form. After students had completed their orientation program, a follow-up e-mail was sent 3 weeks later by the Institutional Research Office for those who had not yet taken the survey. At the end of the summer, a final e-mail was sent to all students who had gone through the orientation program but had not taken the survey. For both years of data collection, students were informed not to include their names on the survey to protect confidentiality and anonymity. Additionally, after data were collected, any identifying information that was included on the surveys (e.g., Internet protocol address) was removed, making it impossible to determine the names of specific participants. The instruments used for this study represent a subset of the entire survey at both data collection points, and students were informed that their participation was completely voluntary.

\section{Results}

First, using both the 2006 and 2007 samples, we conducted descriptive analyses on the four calling items. Nine percent of the sample replied that having a calling to a particular kind of work was not at all true of them, and $44 \%$ replied that having a career calling was either mostly or totally true of them (see Figure 1). Also, 28\% of the sample reported that searching for a calling was either mostly or totally true of them (see Figure 1).

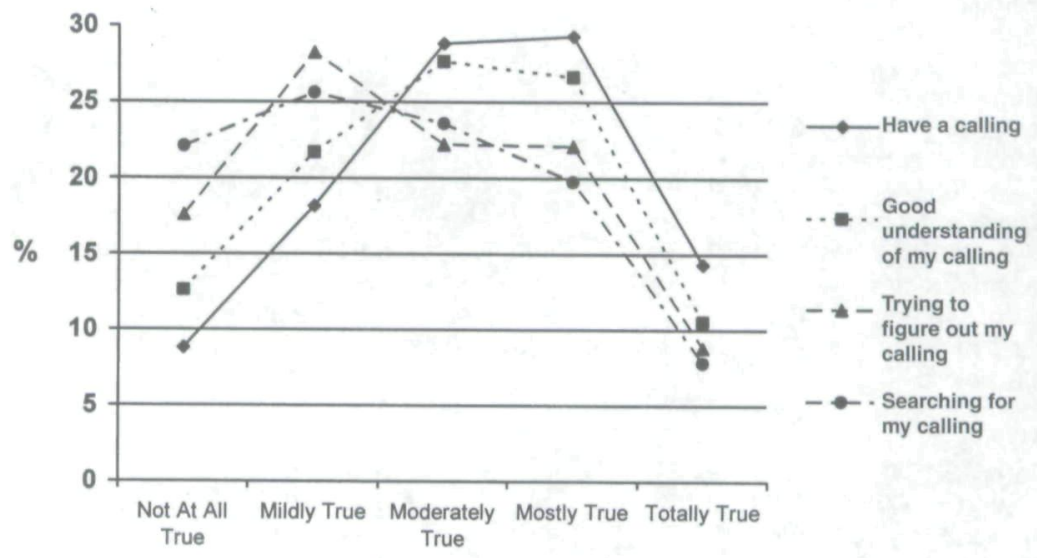

FIGURE 1

Responses to Presence of and Search for Calling Items 
Next, three one-way analyses of variance were used to examine differences in the presence of, and search for, a calling on the basis of a range of demographic variables across both samples. A Bonferroni correction was used to interpret significant findings at the $p<.01$ level $(.05 / 3=.017)$. As shown in Table 1 , significant differences $(p<.01)$ were found on the presence of a calling within race and educational aspiration groups. To further explore these differences, Tukey's post hoc tests were used to compare individual categories within each of these groups.

Results indicated that students planning on pursuing postmaster's degrees, such as law, doctoral, or medical degrees, were modestly more likely to report a career calling than were those planning on pursuing only a bachelor's or master's degree. Additionally, students who were African American felt slightly more called to their careers than did Asian American or European American students (see Table 1). Nevertheless, although each of these relations was significant at the $p<.01$ level, the effect sizes were minimal and need to be considered cautiously (Cohen, 1988). Regarding the search for a calling, significant differences were found within educational aspiration groups in that those seeking law, doctoral, or medical degrees were less likely to be searching for a calling than were those planning to obtain a bachelor's or master's degree (see Table 1). Again, however, the effect size of these differences was small to moderate.

Finally, as seen in Table 2, correlations were completed to examine the relations of the presence of, and search for, a calling with religiousness,

TABLE 1

\section{One-Way ANOVAs Exploring Group Differences in the Presence of and Search for a Calling by Gender, Race, and Educational Aspirations With the $2006(n=3,091)$ and $2007(n=2,432)$ Samples}

\begin{tabular}{|c|c|c|c|c|c|c|c|c|c|c|}
\hline \multirow[b]{2}{*}{ Variable } & \multicolumn{5}{|c|}{ Presence } & \multicolumn{5}{|c|}{ Search } \\
\hline & $M$ & $S D$ & $F$ & $p$ & $\eta^{2}$ & $M$ & $S D$ & $F$ & $p$ & $\eta^{2}$ \\
\hline Gender & & & 0.32 & .57 & .00 & & & 4.03 & .05 & .00 \\
\hline $\begin{array}{l}\text { Male }(n=2,466) \\
\text { Female }\end{array}$ & 6.21 & 2.20 & & & & 5.35 & 2.26 & & & \\
\hline$(n=2,545)$ & 6.24 & 2.30 & & & & 5.48 & 2.32 & & & \\
\hline Race & & & 6.86 & .00 & .01 & & & 7.96 & .00 & .01 \\
\hline $\begin{array}{l}\text { European Ameri- } \\
\text { can }(n=3,170) \\
\text { African American }\end{array}$ & 6.21 & 2.26 & & & & 5.32 & 2.30 & & & \\
\hline $\begin{array}{l}(n=651) \\
\text { Latino American }\end{array}$ & 6.54 & 2.29 & & & & 5.44 & 2.44 & & & \\
\hline $\begin{array}{c}(n=310) \\
\text { Asian American }\end{array}$ & 6.31 & 2.18 & & & & 5.51 & 2.33 & & & \\
\hline$(n=460)$ & 6.17 & 2.22 & & & & 5.67 & 2.39 & & & \\
\hline $\begin{array}{l}\text { Edu. asp. } \\
\text { Bachelor's }\end{array}$ & & & 48.33 & .00 & .04 & & & 12.30 & .00 & .01 \\
\hline $\begin{array}{l}(n=654) \\
\text { Master's }\end{array}$ & 5.89 & 2.29 & & & & 5.60 & 2.31 & & & \\
\hline$(n=2,169)$ & 5.99 & 2.22 & & & & 5.54 & 2.30 & & & \\
\hline Law $(n=377)$ & 6.58 & 2.17 & & & & 5.28 & 2.30 & & & \\
\hline Doctoral $(n=854)$ & 6.67 & 2.17 & & & & 5.14 & 2.36 & & & \\
\hline Medical $(n=654)$ & 7.14 & 2.02 & & & & 4.93 & 2.30 & & & \\
\hline
\end{tabular}

Note. ANOVAs $=$ analyses of variance; Presence $=$ presence of a calling; Search $=$ search for a calling; Edu. asp. = educational aspirations. 
TABLE 2

Correlations Between the Calling Variables and Religiousness, Life Meaning, the Search for Life Meaning, and Life Satisfaction With the 2007 Sample $(n=2,432)$

\begin{tabular}{lcccccc}
\hline \hline Variable & $\mathbf{1}$ & $\mathbf{2}$ & $\mathbf{3}$ & \multicolumn{1}{c}{$\mathbf{4}$} & \multicolumn{1}{c}{$\mathbf{5}$} & \multicolumn{1}{c}{6} \\
\hline 1. Presence of a calling & - & $-.33^{\star \star}$ & $.10^{\star}$ & $.39^{\star \star}$ & .00 & $.16^{\star \star}$ \\
2. Search for a calling & & - & .02 & $-.18^{\star}$ & $.28^{\star \star}$ & $-.12^{*}$ \\
3. Religiousness & & & - & $.27^{\star \star}$ & .02 & $.08^{\star}$ \\
4. Life meaning & & & & - & .02 & $.43^{\star \star}$ \\
5. Search for life meaning & & & & & - & $-.09^{*}$ \\
6. Life satisfaction & & & & & & - \\
$M$ & 6.04 & 5.36 & 27.83 & 10.59 & 10.10 & 25.71 \\
$S D$ & 2.27 & 2.32 & 7.57 & 2.36 & 2.78 & 5.94 \\
\hline
\end{tabular}

${ }^{*} p<.05,{ }^{* *} p<.01$.

life meaning, the search for life meaning, and life satisfaction using only the 2007 sample. The presence of a calling was found to weakly correlate with religiousness and life satisfaction and moderately correlate with life meaning. Additionally, the search for a calling was found to weakly, negatively correlate with life meaning and life satisfaction and positively correlate with the search for life meaning. The amount of variance each of these significant variables added to the prediction of calling was also explored to determine practical significance. For the presence of a calling, effect sizes ranged from small to moderate, and the variance contributed $\left(r^{2}\right)$ by each of these constructs was as follows: religiousness $(1 \%)$, life satisfaction $(3 \%)$, and life meaning (15\%). For the search for a calling, effect sizes also ranged from small to moderate, with the variance contributed $\left(r^{2}\right)$ by each of these constructs as follows: life satisfaction ( $1 \%)$, life meaning $(3 \%)$, and the search for life meaning $(8 \%)$. Last, the presence of a calling was found to negatively correlate with the search for a calling; this was a moderate relation.

\section{Discussion}

The results of this study provide initial evidence of the degree to which incoming university students endorse the presence of, or search for, a career calling. On the basis of the descriptive statistics from all four items measuring these constructs, the first major point to consider is that the calling variables may be salient for certain college students-a population in which these variables have been seldom studied. In this exploratory study, the finding that more than $40 \%$ of students believed that having a calling was mostly or totally true of themselves may speak to the notion that a significant portion of students currently entering college seem cognizant of this term as it applies to their career. These findings are similar to those of Wrzesniewski et al. (1997), who found that approximately one third of working adults endorsed a career calling. Additionally, students who do not currently have a calling are moderately more likely to be searching for one, and it is critical that future researchers tease out if obtaining a calling and searching for a calling are two ends of a spectrum or can overlap in some capacity. 
Differences found in scores for the presence of, and search for, a calling across gender, race, and educational aspirations provide a more detailed description of the importance of these variables among subgroups. For both constructs, no significant differences were found by gender, suggesting that men are just as likely to have, or be searching for, a calling as women. Additionally, although significant group differences were found by race, these differences were extremely small, which suggests that the experience of a career calling is more similar than different across the groups studied here.

For both calling constructs, more substantial significant differences were found in the educational aspiration groupings. It seems that those students planning to obtain more advanced degrees (e.g., doctoral, medical, law) may be moderately more likely to already feel called to a certain line of work and moderately less likely to be searching for a calling than are those seeking a bachelor's or master's degree. This finding coincides with Davidson and Caddell's (1994) results with working populations in that the authors found that as educational levels increased so did the sense of calling. For the current sample, this result may suggest that careers such as professor, doctor, and lawyer are more widely considered callings than are other professions. Students may view these jobs as giving them a greater chance to help others and to find personal life meaning, two components that we believe are critical to the definition of a career calling. Nevertheless, this point remains very speculative, because the connection between a student's calling and his or her ultimate career choice was not assessed in the current study and future longitudinal research would be needed to address this notion.

The correlational results suggest that the calling variables have some overlap with life meaning and life satisfaction and also, perhaps somewhat surprisingly, only a minimal overlap with religiousness. Students who were more likely to endorse a career calling were also moderately more likely to believe that their lives were meaningful, which corroborates the moderate correlation of life meaning and the sense of a calling found by Dik et al. (2008). This finding may make intuitive sense because for students entering college, they may be just starting to integrate their major or career into their greater identity, and those with higher levels of a career calling may have accomplished this more fully. One pathway to feel that one's life is purposeful is through a career, and those students who have a career calling may use this as a guiding mechanism for the promotion of life meaning. Additionally, those students searching for a career calling were moderately more likely to be searching for life meaning. This finding suggests that students who may be seeking general life meaning may also be looking for meaning in their careers, perhaps through finding a career calling. The strength of the relations among the calling and meaning variables are suggestive of constructs that overlap, but are empirically distinct.

Results also revealed that those with higher levels of a career calling tend to be only minimally more satisfied with their lives in general. This finding is at odds with the stronger calling-satisfaction links found in the Wrzesniewski et al. (1997) study using an adult population. One possible reason for the weak link between these variables is that students in this study were several years away from full-time employment. Thus, for college students 
not currently working, the degree to which one has a calling to one's future career may have only a minimal effect on one's present life satisfaction.

Finally, it is important to note the small, almost nonexistent relation found between the presence of a career calling and religiousness. Given previous theory and research on this construct, which have found stronger correlations (Davidson \& Caddell, 1994; Dik et al., 2008), one might assume that students who endorse a calling may be highly more likely to be religious, given that this construct is very often associated with religion (Dik \& Duffy, 2009). Nevertheless, it seems that students are not connecting their levels of religiousness with their levels of calling. It may be that for incoming students, a calling has little religious connection but rather refers to a career one is "meant to do." Additionally, given that the internal consistency of the Intrinsic Religiousness Scale was moderate, it is possible that measurement error could have also contributed to the lack of relation between these constructs. Clearly, further study is needed to further explore the relation between these constructs.

\section{Implications for Practice}

For practitioners involved in counseling or advising students with major- or career-related issues, it is critical that a thorough understanding is obtained about the wide range of variables involved in a student's decision-making process. These include traditional variables such as interests, skills, and values, but may also include the concept of a career calling. Some students may arrive at a college or university already feeling a strong career calling, others may be actively searching for one, and others may not view either of these constructs as salient for themselves. Because very little research has been completed on these groups, each may provide unique challenges for student affairs professionals and counselors. Additionally, having a career calling, or searching for one, may be related to a student's career decision making given that prior research has shown that students with a career calling report using this as a factor in their future career choices (Dobrow, 2006; Royce-Davis \& Stewart, 2000). Counselors might work with groups of students who have a career calling, or are searching for one, in unique ways (Dik, Duffy, \& Eldridge, 2009).

\section{Students With the Presence of a Calling}

In terms of understanding the salience of these constructs for particular students, perhaps the most important first step for any counselor is to merely ask if a student feels he or she has a career calling or is searching for one (Dik et al., 2009). Considering that more than $40 \%$ of the students in this study felt having a calling was mostly true or totally true of themselves (in a public, nonreligious university), it seems critical that this construct be addressed in career counseling. For students who have a career calling, it is advised to let the student take the lead in what this means to his or her career development. Counselors can help explore what the student's definition is of this construct; where he or she sees the calling originating; if it is religious in nature; and if the career the student feels called to do is congruent with his or her values, interests, skills, and abilities. For this final point, it is possible that for a subset of 
clients, having a career calling is part of a larger set of life values and fits with a client's greater sense of life purpose. For other clients, it is possible that the calling they feel to a particular career (e.g., to become a teacher) is at odds with their values (e.g., to make a lot of money) or parental expectations. Working with a client to balance these concerns may be a critical skill for counselors.

\section{Students Searching for a Calling}

Additionally, for students who report that they are searching for a calling, advisers and counselors are encouraged to help facilitate this search by discussing the cues whereby a student would know if he or she began to feel called (Dik et al., 2009). Of the students in this study, 28\% reported that trying to figure out their career calling was mostly or totally true of them. Although no prior research has explored this topic, it may be that this group of students would be more likely to pursue counseling, given that being in search of a calling has been linked to uncertainty about one's career choice (Duffy \& Sedlacek, 2007). It is assumed that students will likely feel called to careers that are congruent with at least some of their vocational interests, skills, and values, and students should be advised to conduct a deep, personal exploration of these variables as a means of discerning possible callings. In brief, counselors are encouraged to make calling a part of their vocabulary when advising students on career-related issues and, ultimately, assist them in their calling search process or offer support to help make their current career calling a reality. The results of this study suggest that this construct is important to students and knowledge of its effect on a student's career is just beginning to be discovered.

\section{Limitations and Future Directions}

The results, discussion, and practice implications of this study need to be considered in light of a number of limitations. First, this study was exploratory in nature and used participants who were incoming, 1st-year students at a large, mid-Atlantic, public university. Thus, although the sample could be considered large and diverse, it is difficult to extend these results to students further along in their college education or those who attend private or religious schools. Second, a major limitation concerns the instruments used to measure the calling items and the life meaning items. These instruments had very little reliability or validity data, and each construct (i.e., presence of a calling, search for a calling, life meaning, and search for life meaning) was assessed by a scale composed of two items. Additionally, the instruments used to assess the presence of, and search for, a career calling had only five scale points per item and were unable to ascertain how students were defining the term.

Third, because the calling scales were not compared with any vocational outcome variable other than educational aspirations, the degree to which these findings can be applied to career counseling should be considered cautiously. That is, although a portion of students within this study endorsed having a career calling or searching for one, it is impossible to determine whether this has any effect on their career decision making or likelihood to seek counseling. Fourth, most of the demographic differences with the calling variables produced small effect sizes and displayed little 
practical significance, and thus need to be considered cautiously. Finally, although students completing this study in the 1st year of data collection participated in a controlled setting with proctors present, it is impossible to ascertain how students in the 2 nd year completed the survey.

Given these limitations of the current study, a number of future research directions are offered. First, a more thorough understanding is needed of how college students interpret the term calling, and this may be best accomplished through qualitative studies, an example of which is the recent study by Hunter et al. (2010). Second, it is critical that more valid and reliable instruments to assess calling are developed for both college and adult populations. Developing these instruments may open up a host of other research directions. These may include tracking how levels of the presence of, or search for, a career calling change over time in college, determining the degree to which one's career calling actually affects one's career choices, and determining what populations of workers are most likely to feel called to their career. Additionally, it may be fruitful to explore how the calling variables relate to frequently studied vocational variables such as interests, values, skills, and personality in an effort to understand if those who have a career calling have a particular vocational profile. In sum, because so little research has been conducted to date with these constructs, the research opportunities are expansive and we hope that the results of the current study may serve as an impetus for added attention to be paid to this research area.

\section{References}

Brewer, E. W. (2001). Vocational Souljourn Paradigm: A model of adult development to express spiritual wellness as meaning, being, and doing in work and life. Counseling and Values, 45, 83-93.

Bunderson, J. S., \& Thompson, J. A. (2009). The call of the wild: Zookeepers, callings, and the double-edged sword of deeply meaningful work. Administrative Science Quarterly, 54, 32-57.

Cohen, J. (1988). Statistical power analysis for the behavioral sciences (2nd ed.). Hillsdale, NJ: Erlbaum.

Constantine, M. G., Miville, M. L., Warren, A. K., Gainor, K. A., \& Lewis-Coles, M. E. L. (2006). Religion, spirituality, and career development in African American college students: A qualitative inquiry. The Career Development Quarterly, $54,227-241$.

Davidson, J. C., \& Caddell, D. P. (1994). Religion and the meaning of work. Journal for the Scientific Study of Religion, 33, 135-147.

Diener, E., Emmons, R. A., Larsen, R. J., \& Griffin, G. (1985). Satisfaction with life. Journal of Personality and Social Psychology, 48, 94-105.

Dik, B. J., \& Duffy, R. D. (2009). Calling and vocation at work: Definitions and prospects for research and practice. The Counseling Psychologist, 37, 424-450.

Dik, B. J., Duffy, R. D., \& Eldridge, B. (2009). Calling and vocation in career counseling: Recommendations for promoting meaningful work. Professional Psychology: Research and Practice, 40, 625-632.

Dik, B. J., Sargent, A. M., \& Steger, M. F. (2008). Career development strivings: Assessing goals and motivation in career decision-making and planning. Journal of Career Development, 35, 23-41.

Dik, B. J., \& Steger, M. F. (2006, July). Work as a calling: Randomized trial of a callingbased career development workshop. Paper presented at the National Career Development Association Global Conference, Chicago, IL. 
Dobrow, S. R. (2006). Having a calling: A longitudinal study of young musicians. Dissertation Abstracts International: Section A. Humanities and Social Sciences, 67(05), 1808.

Duffy, R. D. (2006). Spirituality, religion, and career development: Current status and future directions. The Career Development Quarterly, 55, 52-63.

Duffy, R. D. (2010). Spirituality, religion, and work values. Journal of Psychology and Theology, 38, 52-61.

Duffy, R. D., \& Blustein, D. L. (2005). The relationship between spirituality, religiousness, and career adaptability. Journal of Vocational Behavior, 67, 429-440.

Duffy, R. D., \& Dik, B. J. (2009). Beyond the self: External influences in the career development process. The Career Development Quarterly, 58, 29-43.

Duffy, R. D., \& Lent, R. W. (2008). Relation of religious support to career decision selfefficacy in college students. Journal of Career Assessment, 16, 360-369.

Duffy, R. D., \& Sedlacek, W. E. (2007). The presence of and search for a calling: Connections to career development. Journal of Vocational Behavior, 70, 590-601.

Gorsuch, R. L., \& McPherson, S. E. (1989). Intrinsic/extrinsic measurement: I/E-Revised and single-item scales. Journal for the Scientific Study of Religion, 28, 348-354.

Hall, D. T., \& Chandler, D. E. (2005). Psychological success: When the career is a calling. Journal of Organizational Behavior, 26, 155-176.

Hitchings, W. E., Luzzo, D. A., Retish, P., Horvath, M., \& Ristow, R. S. (1998). Identifying the career development needs of college students with disabilities. Journal of College Student Development, 39, 23-32.

Hunter, I., Dik, B. J., \& Banning, J. H. (2010). College students' perceptions of calling in work and life: A qualitative analysis. Journal of Vocational Behavior, 76, 178-186.

Leak, G. K. (1992). Religiousness and social interest: An empirical assessment. Individual Psychology: Journal of Adlerian Theory, Research \& Practice, 48, 288-301.

Lippa, R. (1998). Gender-related individual differences and the structure of vocational interests: The importance of the people-things dimension. Journal of Personality and Social Psychology, 74, 996-1009.

Lips-Wiersma, M. (2002). The influence of spiritual "meaning making" on career behavior. Journal of Management Development, 21, 497-520.

Luzzo, D. A. (Ed.). (2000). Career counseling of college students: An empirical guide to strategies that work. Washington, DC: American Psychological Association.

Meinster, M. O., \& Rose, K. C. (2001). Longitudinal influences of educational aspirations and romantic relationships on adolescent women's vocational interests. Journal of Vocational Behavior, 58, 313-327.

Niles, S. G., Erford, B. T., Hunt, B., \& Watts, R. H. (1997). Decision-making styles and career development in college students. Journal of College Student Development, 38, 479-488.

Park, C. L., Cohen, L., \& Murch, R. (1996). Assessment and prediction of stress-related growth. Journal of Personality, 64, 71-105.

Pavot, W., \& Diener, E. (1993). Review of the Satisfaction With Life Scale. Psychological Assessment, 5, 164-172.

Peterson, C., Park, N., Hall, N., \& Seligman, M. E. P. (2009). Zest and work. Journal of Organizational Behavior, 30, 161-172.

Royce-Davis, J., \& Stewart, J. (2000). Addressing the relationship between career development and spirituality when working with college students. Retrieved from ERIC database. (ED452444)

Salsman, J. M., Brown, T. L., Brechting, E., \& Carlson, C. (2005). The link between religion and spirituality and psychological adjustment: The mediating role of optimism and social support. Personality and Social Psychology Bulletin, 31, 522-535.

Serow, R. C. (1994). Called to teach: A study of highly motivated preservice teachers. Journal of Research and Development in Education, 27, 65-72.

Serow, R. C., Eaker, D., \& Ciechalski, J. (1992). Calling, service, and legitimacy: Professional orientations and career commitment among prospective teachers. Journal of Research and Development in Education, 25, 136-141. 
Steger, M. F., Frazier, P., Oishi, S., \& Kaler, M. (2006). The Meaning in Life Questionnaire: Assessing the presence of and search for meaning in life. Journal of Counseling Psychology, 53, 80-93.

Super, D. E. (1990). A life-span, life-space approach to career development. In D. Brown, L. Brooks, \& Associates (Eds.), Career choice and development: Applying contemporary theories to practice (2nd ed., pp. 197-261). San Francisco, CA: Jossey-Bass.

Tomlinson, M. J., \& Fassinger, R. E. (2003). Career development, lesbian identity development, and campus climate among lesbian college students. Journal of College Student Development, 44, 845-860.

Whiston, S. C., \& Keller, B. K. (2004). The influences of the family of origin on career development: A review and analysis. The Counseling Psychologist, 32, 493-568.

Worthington, R. L., Flores, L. Y., \& Navarro, R. L. (2005). Career development in context: Research with people of color. In S. D. Brown \& R. L. Lent (Eds.), Career development and counseling: Putting theory and research to work (pp. 225-252). Hoboken, NJ: Wiley.

Wrzesniewski, A., McCauley, C., Rozin, P., \& Schwartz, B. (1997). Jobs, careers, and callings: People's relations to their work. Journal of Research in Personality, 31, 21-33. 
Copyright of Career Development Quarterly is the property of National Career Development Association and its content may not be copied or emailed to multiple sites or posted to a listserv without the copyright holder's express written permission. However, users may print, download, or email articles for individual use. 